\title{
O capital escravista-mercantil: caracterização teórica e causas históricas de sua superação
}

Julio MANuel Pires e Iraci del NERO DA COSTA

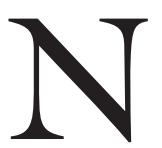

ESTE ARTIGO, além de apresentarmos a caracterização teórica de uma específica forma de existência do capital - o capital escravistamercantil -, ocupamo-nos, agora no plano empírico, das causas históricas imediatas que conduziram, nas Américas, à superação desta particular forma do capital.

\section{Uma forma específica de capital}

Como sabido, Marx considerou, explícita e largamente, três formas de existência do capital. A correspondente ao capital comercial assim foi caracterizada: “...o comércio e inclusive o capital comercial são anteriores ao regime de produção capitalista e constituem na verdade a modalidade livre do capital mais antiga de que nos fala a história" (Marx, 1965, III:314). A segunda diz respeito ao capital usurário (ou de empréstimo) e também foi vista como forma autônoma e independente: "O capital a juros ou capital usurário, para empregar o termo arcaico, figura com seu irmão gêmeo, o capital comercial, entre as formas antediluvianas do capital que precedem há muito tempo o regime de produção capitalista e com as quais nos encontramos nas mais diversas formações econômicas da sociedade" (Marx, 1965, III:555) (...) "A usura, como o comércio, explora um regime de produção dado, não o cria, se comporta exteriormente ante ele” (Marx, 1965, III:569). A última concerne ao capital industrial e é própria do modo de produção capitalista: "Se o dinheiro pode ser investido nesta forma é, simplesmente, porque a força de trabalho se encontra separada de seus meios de produção (incluindo os meios de subsistência, como meios de produção da própria força de trabalho) e porque esta separação só pode remediar-se de um modo: vendendo a força de trabalho ao possuidor dos meios de produção" (Marx, 1964, II:33).

A nosso ver, além das três acima arroladas, Marx sugeriu uma quarta forma de existência do capital. Assim, ao tratar dos efeitos decorrentes do 
desenvolvimento do comércio e do capital comercial, afirmou: "No mundo antigo, os efeitos do comércio e o desenvolvimento do capital comercial se traduzem sempre na economia escravista; e segundo o ponto de partida, conduzem simplesmente à transformação de um sistema escravista patriarcal, encaminhado à produção de meios diretos de subsistência, em um sistema orientado para a produção de mais valia" (Marx, 1965, III:321). Estaríamos, pois, em face da exploração de mais-valia nos quadros do escravismo antigo. Tal produção de mais-valia far-se-ia presente, igualmente, em áreas do Novo Mundo quando ainda imersas no escravismo: "Por isso nos Estados norte-americanos do Sul o trabalho dos negros conservou certo suave caráter patriarcal enquanto a produção se circunscrevia substancialmente às próprias necessidades. Porém, tão logo a exportação de algodão passou a ser uma mola vital para aqueles Estados, a exploração intensiva do negro se converteu em fator de um sistema calculado e calculador, chegando a dar-se casos de esgotar-se em sete anos de trabalho a vida do trabalhador. Agora, já não se tratava de obter dele uma certa quantidade de produtos úteis. Agora, tudo girava em torno da produção de mais valia pela mais valia mesma" (grifos de Marx, 1964, I:181-182).

Trata-se, pois, da mesma forma de existência do capital, agora a viger no âmbito do escravismo moderno, também identificado como escravismo colonial (1). Enfim, mais-valia, valor que se valoriza, portanto capital; porém, uma forma específica de existência do capital, pois calcada na produção de mercadorias com base no escravismo (2). Neste texto, como avançado, consideramos essa particular forma de capital, a qual denominamos escravista-mercantil, visando a estabelecer algumas de suas principais características.

\section{Limitações lógicas e históricas}

Ao capital escravista-mercantil impõem-se limitações de caráter lógico e histórico, as quais devem ser tomadas como facetas de um todo único e solidário, vale dizer, devem ser entendidas, a depender das condições concretas, como lógico-históricas ou histórico-lógicas.

No passado mais longínquo tal forma apresentou-se como exceção no âmbito do escravismo patriarcal inclusivo. Segundo Marx, "Sem embargo, é evidente que naquelas sociedades econômicas nas quais não predominava o valor de troca, mas sim o valor de uso do produto, o trabalho excedente se acha circunscrito a um setor mais ou menos amplo de necessidades, sem que do caráter mesmo da produção brote uma fome insaciável de trabalho excedente. Por isso, onde na Antiguidade se revela o mais espanto- 
so trabalho sobrante é ali onde se trata de produzir o valor de troca em sua forma específica de dinheiro, quer dizer, na produção de ouro e prata. Nestes setores, a forma oficial do trabalho excedente são os trabalhos forçados levados até a morte. [...] Sem embargo, no mundo antigo isto não é mais do que excepcional" (grifos de Marx, 1964, I:181).

A nosso ver, tal restrição de caráter lógico-histórico foi perfeitamente elucidada por Gorender: "O impasse da escravidão romana decorreu da impossibilidade de um modo de produção escravista patriarcal se converter em modo de produção escravista mercantil, nas condições do mundo antigo. (...) Roma não podia implantar uma economia exportadora em seu próprio território, nem nos territórios das províncias conquistadas. A única exceção, frisada por Marx, foi a Sicília, onde latifúndios escravistas cultivavam trigo para suprimento da Metrópole. (...) A fim de que se convertesse em escravismo mercantil dominante, seria preciso que a produção escravista se acoplasse a um mercado externo dotado de proporções que as cidades antigas ficaram longíssimo de proporcionar. (...) Roma estava impedida de fazer-se colônia econômica de si mesma e engendrar o escravismo colonial. Daí o impasse histórico insolúvel, traduzido na estagnação tecnológica e no encarecimento crescente da produção por meio de escravos, cada vez menos capaz de constituir a base do Estado imperial" (grifos de Gorender, 1992:160-161).

Conquanto pudéssemos admitir, hipoteticamente, a existência de pólos escravistas autônomos a produzir mercadorias e a comerciar entre si - e esta seria a única maneira de se superar a limitação de ordem lógica aqui exposta -, devemos renunciar a tal conjectura, pois, como sabido, o escravismo antigo é que se viu superado sem conhecer o arranjo hipotético aqui aventado. No que tange às áreas do mundo moderno nas quais se deu a revivescência do escravismo, impõe-se restrição de ordem histórico-lógica, pois agora a existência do capital escravista-mercantil viu-se condicionada pelo modo de produção capitalista já existente na Europa ocidental e que deitava raízes, como é próprio de sua natureza, em todo o planeta; destarte, para Marx, à medida que o capital industrial "se vai apoderando da produção social, revoluciona a técnica e a organização social do processo de trabalho, e com elas o tipo histórico-econômico de sociedade. As outras modalidades de capital que apareceram antes desta no seio de estados sociais de produção pretéritos ou condenados a morrer, não só se subordinam e se amoldam a ele no mecanismo de suas funções, mas também que já se movem sobre a base daquele, e portanto vivem e morrem, se mantém e desaparecem com este sistema que lhes serve de base" (Marx, 1964, II:51). 
Embora o autor estivesse a se referir, provavelmente, ao capital comercial e ao capital usurário, entendemos que tais considerações se mostram plenamente aplicáveis ao caso do capital escravista-mercantil. Ademais, parece-nos que as mesmas lançam luz sobre referências explícitas efetuadas por Marx com respeito ao escravismo moderno. Vejamo-las: "A escravidão dos negros - uma escravidão puramente industrial - que desaparece sem mais e é incompatível com o desenvolvimento da sociedade burguesa, pressupõe a existência de tal sociedade: se paralelamente a esta escravidão não existirem outros estados livres com trabalho assalariado, todas as condições sociais nos estados escravistas assumiriam formas pré-civilizadas" (grifos de Marx, 1980:159). Na mesma obra, o autor retoma o tema: "Isto não exclui que dentro do sistema burguês de produção seja possível a escravidão em tal ou qual ponto. Porém a mesma só é possível porque não existe em outros pontos, e se apresenta como uma anomalia frente ao sistema burguês mesmo" (Marx, 1980:425). O mesmo tom é empregado quando trata dos proprietários escravistas: "Que os donos de plantações na América não apenas sejam chamados agora capitalistas, mas que eles o sejam, se baseia no fato de que eles existem como uma anomalia dentro de um mercado mundial baseado no trabalho livre" (grifo de Marx, 1980:476).

Assim, no mundo moderno, a produção de mercadorias alicerçada na mão-de-obra escrava só se tornou possível por tratar-se de produção voltada essencialmente para a exportação, a qual, por seu turno, destinava-se sobretudo aos mercados da Europa, onde se revelava dominante o modo de produção capitalista. Três outros pontos devem, ainda, ser fixados:

- a escravidão localizada não é incompatível com o modo de produção capitalista, mas com o desenvolvimento do mesmo e, portanto, irremediavelmente fadada ao desaparecimento;

- estamos em face de um escravismo produtor de mercadorias (escravidão puramente industrial) e dependente dos mercados mundiais aos quais deve sua existência (3);

- os escravistas são capitalistas, vale dizer, acrescentamos nós, personificam o capital escravista-mercantil.

Das considerações expendidas na abertura deste tópico, e das conclusões arroladas, inferimos imediatamente que a forma capital escravista-mercantil não pode existir autônoma e independentemente, pois sua existência pressupõe, na antigüidade, o modo de produção escravista e, em passado mais recente, o modo de produção capitalista. Ademais, sua subsistência também revela-se condicionada e subordinada a tais modos de produção. Como no caso do capital comercial e do capital usurário, estamos em face 
de uma forma de capital que não traz em si as condições de sua existência e de sua subsistência. Aquelas duas primeiras, justamente por mostrarem-se livres, autônomas e independentes com respeito a um específico modo de produção, definem-se como dependentes de modos de produção que para as mesmas se revelam como dados e, nesta medida, cada uma de tais formas é incapaz de criar as condições necessárias à sua existência e subsistência, operando, pois, de modo parasitário com respeito aos aludidos modos de produção; repisemos aqui a afirmação de Marx: "A usura, como o comércio, explora um regime de produção dado, não o cria, se comporta exteriormente a ele" (Marx, 1965, III:569).

Como evidenciado, o capital escravista-mercantil, por não trazer implícita a plasticidade do comercial e usurário, é imediatamente dependente de uma específica relação de produção (a escravista) e igualmente dependente de específicos modos de produção (o escravista e o capitalista). Assim, embora não se defina como parasitária, porque produtora de mercadorias, tal forma não traz em si seus pressupostos não sendo capaz, portanto, de per se, pô-los ou repô-los; vale dizer, as condições objetivas de sua existência e subsistência lhe são externas e dadas pelos modos de produção retro assinalados. Logo, a forma capital escravista-mercantil é incapaz de dar embasamento a um modo de produção que lhe seja próprio e que dela decorra. Como sabido, o mesmo não ocorre com o capital industrial quanto à referida capacidade, à qual Marx emprestou tratamento explícito e minudente (Cf. Marx, 1980:420-421).

Eis, pois, delineadas, algumas das principais características da forma de capital em epígrafe, outras mais seguem no decorrer do texto.

\section{Um ponto a discutir}

A nosso juízo, existem razões suficientes e plenamente aceitáveis que explicam o fato de Marx não haver se detido mais demoradamente no estudo do escravismo antigo e, em particular, do moderno.

Interessado, essencialmente, em analisar a lógica do capital industrial e em estabelecer os caminhos teóricos e práticos aptos a concretizar a superação do modo de produção capitalista, o autor desenvolveu um método em face do qual se tornou dispensável o estudo do escravismo antigo: “... nosso método põe em relevo os pontos em que deve ser introduzida a análise histórica, ou nas quais a economia burguesa como mera forma histórica do processo de produção aponta mais além de si mesma aos precedentes modos de produção históricos. Para analisar as leis da economia burguesa não é necessário, pois, escrever a história real das relações de produção. Po- 
rém a correta concepção e dedução das mesmas, enquanto relações originadas historicamente, conduzem sempre às primeiras equações - como os números empíricos por exemplo nas ciências naturais - que apontam para um passado que jaz por trás deste sistema. Tais indícios, conjuntamente com a concepção correta do presente, concedem a chave para a compreensão do passado, um trabalho à parte, que pretendemos poder abordar em outra ocasião" (grifos de Marx, 1980:422). Infelizmente, como sabemos, o autor não pôde realizar o trabalho prometido. Já a consideração pormenorizada do escravismo moderno seria ociosa à medida que o mesmo se trata, tão-somente, de uma anomalia dentro de um mercado mundial baseado no trabalho livre, anomalia esta que desaparece sem mais e é incompativel com o desenvolvimento da sociedade burguesa (Cf. citações acima).

Tais argumentos poderiam ser avocados para explicar o fato de o autor não haver contemplado, explicitamente, a forma capital escravista-mercantil; além disso, também justificariam a assertiva: "O capital industrial é a única forma de existência do capital em que é função deste não apenas a apropriação da mais valia ou do produto excedente, mas também sua criação" (Marx, 1964, II:51). A nosso ver, o capital industrial não é a única forma de capital a cumprir tal papel, pois entendemos que tal função também é desempenhada pelo capital escravista-mercantil, o qual, não obstante, não deixa, por isto, de ser dependente e subordinado ao modo de produção capitalista inclusivo.

Assim, no caso da colônia lusa em terras americanas, a criação da maisvalia decorria da ação do capital escravista-mercantil, vale dizer, embora isolado dos mercados externos e, portanto, da órbita da circulação - o que será discutido no próximo tópico -, a esfera da produção interna colocavase inteiramente em sua órbita e era dominada pelo mesmo. Tal dominância, que não deve ser entendida em termos absolutos, estendia-se à produção de mercadorias (exportáveis ou não), de valores de uso e de serviços, abarcando, também, a alocação de fatores e recursos e espraiando-se pela circulação interna. Afetava, ainda, a geração e distribuição da renda, a escala da produção, o tamanho das plantas instaladas, as técnicas utilizadas e os elementos afetos à qualificação da mão-de-obra. Enfim, sua presença condicionava toda a economia colonial bem como as relações estabelecidas no processo de produção, projetando-se, ademais, na vida social e política da colônia. Disto deve-se inferir que os segmentos sociais e econômicos não vinculados imediatamente ao escravismo também se viam influenciados e, em larga medida, determinados, sobretudo no que tange à definição dos limites do espaço econômico em que lhes era dado atuar, pelo capital escravista-mercantil. 
Parece-nos desnecessário lembrar que é justamente em tamanha dominância que se assenta o engano daqueles que pensam encontrar aqui o assim chamado escravismo capitalista ou propugnam pela existência de um pretenso modo de produção colonial.

\section{A presença do capital comercial}

Tanto no passado mais distante quanto no mais recente, o capital comercial desempenhou papel crucial na gênese das condições objetivas que tornaram possível a constituição e subsistência do capital escravistamercantil. Quanto ao período mais próximo, e com respeito ao Brasil, cumpre-nos tecer algumas considerações adicionais.

Como sabemos, seria difícil superestimar o papel do capital comercial (aliado, no caso, ao capital de empréstimo) quanto ao processo de ocupação, povoamento e valorização das terras que couberam aos portugueses no Novo Mundo; assim, a colônia pode ser vista como uma criação do consórcio estabelecido entre o poder régio e o capital comercial. Ao primeiro, além da estruturação e aparelhamento das instâncias burocráticas e administrativas, coube garantir o acesso à terra - meio de produção básico - aos que demonstrassem deter os cabedais necessários para explorá-la em benefício dos interesses metropolitanos. A geração das demais condições materiais que embasaram o aludido processo ficou, sabemo-lo à farta, a cargo do capital comercial. Destarte, este último encarregou-se do financiamento do empreendimento agrícola no Brasil, do fornecimento de mão-de-obra africana e bens de consumo e de produção oriundos da Europa, bem como monopolizou a colocação da produção colonial nos mercados mundiais. É nesta medida que a colônia pode ser vista como um mero apêndice da economia européia a funcionar como um enclave em permanente expansão e que flutua sobre o nada, pois o é de si e em si mesmo. É este, pois, o locus no qual se desenvolve o capital escravista-mercantil, o qual só podia se comunicar com o mundo que lhe era externo mediante a intermediação do capital comercial. Questão esta fixada com inteira propriedade por Gorender: "O capital mercantil em expansão se incumbiria da função de intermediário entre os extremos, autonomizando a esfera da circulação diante das fontes da produção, sem determinar o caráter dado das relações de produção vigentes em cada um dos extremos" (Gorender, 1992:163).

O arranjo assim constituído, no qual o capital comercial funcionava como interface entre a colônia e os mercados externos, acarretou pelo menos quatro conseqüências que marcaram indelevelmente nossa história e nossa historiografia. 
Em primeiro, dele derivou o "sentido da colonização" como caracterizado por Caio Prado Júnior: "No seu conjunto, e vista no plano mundial e internacional, a colonização dos trópicos toma o aspecto de uma vasta empresa comercial, mais completa que a antiga feitoria, mas sempre com o mesmo caráter que ela, destinada a explorar os recursos naturais de um território virgem em proveito do comércio europeu. É este o verdadeiro sentido da colonização tropical, de que o Brasil é uma das resultantes; e ele explicará os elementos fundamentais tanto no econômico como no social, da formação e evolução histórica dos trópicos americanos. (...) Se vamos à essência da nossa formação, veremos que na realidade nos constituímos para fornecer açúcar, tabaco, alguns outros gêneros; mais tarde ouro e diamantes; depois, algodão, e em seguida café para o comércio europeu. Nada mais que isso. É com tal objetivo, objetivo exterior, voltado para fora do país e sem atenção a considerações que não fossem o interesse daquele comércio, que se organizarão a sociedade e a economia brasileiras. Tudo se disporá naquele sentido: a estrutura, bem como as atividades do país. Virá o branco europeu para especular, realizar um negócio; inverterá seus cabedais e recrutará a mão-de-obra que precisa: indígenas ou negros importados. Com tais elementos, articulados numa organização puramente produtora, industrial, constituir-se-á a colônia brasileira. Este início, cujo caráter manter-se-á dominante através dos três séculos que vão até o momento em que ora abordamos a história brasileira, se gravará profunda e totalmente nas feições e na vida do país" (grifo de Prado Júnior, 1987:31-32) (4).

Como segunda conseqüência, a preeminência do capital comercial no que tange à articulação entre os distintos mercados permitiu a emergência e subsistência de um complexo econômico que tinha suas bases produtivas na colônia, sua fonte básica de mão-de-obra na África e contava com os mercados europeus para a realização da produção exportável.

Em terceiro, o isolamento propiciado pelo capital comercial e pelas práticas mercantilistas possibilitou à economia européia beneficiar-se dos efeitos dinâmicos oriundos do Novo Mundo e garantiu a solidez e a robustez que informaram o escravismo moderno, elementos estes da mais alta relevância para o pleno funcionamento e permanência no tempo da exploração desenvolvida pelo capital escravista-mercantil. Por fim, dado o referido isolamento, o capital escravista-mercantil não só comportou, no âmbito de sua dominância, a existência de articulações que iam muito além dos estreitos limites do capital comercial, mas também propiciou o surgimento de muitas de tais articulações, as quais operavam de sorte a garantir a persistência do capital escravista-mercantil e enriqueciam e diversificavam o quadro econômico e social no qual se movimentavam as populações do Brasil escravista. 


\section{Capital escravista-mercantil: \\ pressupostos e resultados de sua ação}

Conscientes de que nossas postulações poderão ser tomadas como um dispensável exercício votado a prever o passado, aventuramo-nos a estabelecer os pressupostos necessários à existência e subsistência do capital escravista-mercantil; abalançamo-nos, ademais, a identificar os resultados imediatos de sua ação.

Destarte, a aludida forma de capital só pôde emergir porque, concomitantemente, se fizeram presentes as seguintes condições:

- existência prévia do escravismo e de fontes supridoras de cativos; tais fontes apresentam-se segundo uma dupla natureza: as institucionais poder do Estado - que fundamentam política e juridicamente a redução e sujeição de pessoas à condição de cativos e as físicas ou biológicas, que garantem a constituição, reposição e o eventual aumento dos plantéis;

- ausência de alternativas, válidas do ponto de vista econômico, à utilização da mão-de-obra escrava;

- existência de mercados capazes de absorverem as mercadorias produzidas com base na exploração da mão-de-obra escrava;

- indivíduos que se habilitavam, e que contaram com os recursos necessários para tanto, a fornecer mão-de-obra cativa mediante a captura e venda e/ou a mera intermediação (compra e revenda);

- indivíduos que visavam a valorizar valor com base na exploração da mão-de-obra escrava e aos quais se apresentaram disponíveis os recursos necessários à mobilização de meios de produção e de mão-deobra cativa.

A conjugação de tais pressupostos, como avançado, deu ensejo ao surgimento do capital escravista-mercantil. De sua ação decorre, imediatamente, a reposição de alguns daqueles supostos, agora derivados da própria existência do capital escravista-mercantil: os escravistas apoderam-se de parte substantiva da mais-valia gerada no processo de produção, vendo, pois, realizado seu desiderato de valorizar valor; o escravo, trabalhador direto, emerge na mesma condição de sujeição em que entrara no processo produtivo.

Também, imediatamente, e derivando de ambos os pressupostos, dáse a emergência e cristalização, no pólo escravista produtor de mercadorias, de interesses econômicos vinculados ao escravismo, fato que empresta rigi- 
dez a tal sistema de exploração e atua no sentido de sua manutenção e ampliação. Destaca-se que não se verificaram, nos tempos modernos, casos nos quais o simples crescimento vegetativo da população cativa pertencente aos que personificavam o capital escravista-mercantil fosse suficiente para atender às suas necessidades de mão-de-obra escrava (5).

De outra parte, o capital escravista-mercantil só podia atuar mediatamente sobre seus outros pressupostos não lhe sendo dado, portanto, repôlos, pois os mesmos the eram externos e para ele definiam-se como dados. Especificamente, referimo-nos às fontes supridoras de escravos e aos mercados mundiais. Destes elementos dependia, como anotado, a permanência no tempo do capital escravista-mercantil. Com respeito ao segundo, vergamo-nos ao argumento definitivo de Gorender (1982), pois, assim como "Roma estava impedida de fazer-se colônia econômica de si mesma e engendrar o escravismo colonial", o mundo colonial moderno não poderia fazer-se metrópole de si mesmo.

Já no que tange às aludidas fontes supridoras de mão-de-obra cativa lembramos - para evidenciar que não se está a tratar da existência de recursos materiais necessários à compra de escravos - as palavras de Marx: "A compra e venda de escravos é também, quanto a sua forma, compra e venda de mercadorias. Porém o dinheiro não poderia exercer esta função se não existisse a escravidão. Há que partir da existência da escravidão, para que o dinheiro possa ser investido na compra de escravos. Por outro lado, para tornar possível a escravidão não basta que o comprador disponha de dinheiro" (Marx, 1964:II:33).

Evidencia-se, pois, que o capital escravista-mercantil, enquanto tal, mostra-se incapaz de prover todos os elementos necessários à sua reprodução, não podendo, portanto, dar suporte a um específico modo de produção. Este mesmo argumento pode ser avocado para desqualificar a opinião segundo a qual, a contar de determinado ponto de nossa história, cumpria à economia escravista brasileira reproduzir-se autonomamente. Esta tese mostra-se ainda mais equivocada se lembrarmos que o processo de acumulação próprio do capital escravista-mercantil não o liberava dos pressupostos que lhe eram externos; ao contrário, tornava-o ainda mais dependente dos mesmos, pois, à medida em que se dava a ampliação da produção escravista-mercantil, maiores eram suas exigências em termos de suprimento de cativos e de escoamento da produção efetuada. Pode-se concluir, pois, que a constituição, no Brasil, de uma economia reflexa e dependente não decorreu meramente da exploração metropolitana ou do fato de a colônia ter sido votada ao fornecimento de produtos para o comércio europeu, mas 
derivou, essencialmente, da forma de capital cujo predomínio marcou nossa história até 1888 .

De outra parte, acreditamos que o surgimento e desenvolvimento de uma vida econômica relativamente autônoma, voltada para dentro, não só se mostrava compatível com a forma capital escravista-mercantil, mas, em larga medida, dela decorreu. Vários autores já se pronunciaram sobre a questão ora aventada, não obstante, em face das conclusões reportadas neste artigo, necessário se torna voltarmos às seguintes afirmações de Gorender: "A desobstrução metodológica impõe a inversão radical do enfoque: as relações de produção da economia colonial precisam ser estudadas de dentro para fora, ao contrário do que tem sido feito, isto é, de fora para dentro (tanto a partir da família patriarcal ou do regime jurídico da terra, quanto a partir do mercado ou do sistema colonial). A inversão do enfoque é que permitirá correlacionar as relações de produção às forças produtivas em presença e elaborar a categoria de modo de produção escravista colonial na sua determinação específica" (Gorender, 1992:7). Como bem diz o autor, impõe-se um novo enfoque, mas tal mudança não deve nos levar diretamente à formulação do pretendido modo de produção escravista colonial, pois ela passa, necessariamente a nosso ver, pela discussão da categoria capital escravista-mercantil e pelo estabelecimento das conseqüências decorrentes de sua existência.

\section{A fórmula do capital escravista-mercantil}

Embora não nos escapem, os elementos de economia natural próprios do escravismo não serão aqui considerados, uma vez que nos centraremos na fórmula do capital escravista-mercantil em seus termos estritamente lógicos. Daí decorre também que não contemplaremos os assalariados, igualmente presentes nos quadros do escravismo moderno, nem as pessoas livres que, por via de regra na condição de agregados, mediata ou imediatamente vinculavam-se às atividades econômicas desenvolvidas pelos escravistas. Assim procedendo, esperamos poder estabelecer, em termos abstratos evidentemente, a fórmula própria do capital escravista-mercantil.

Contemplada em termos os mais simples e abstratos possíveis, vale dizer, caso consideremos tão-somente os desembolsos pecuniários efetivamente incorridos pelo escravista na compra, à vista, de cativos e de mercadorias - compreendidos aqui meios de produção e bens para consumo destinados à manutenção da escravaria - a serem utilizados excludentemente na produção de bens destinados à comercialização, a representação do capital escravista-mercantil deve obedecer às seguintes condições: 


$$
\mathrm{D}<\mathrm{Dl}_{\mathrm{Mp}}^{\mathrm{De}} \underset{\mathrm{Me}}{\mathrm{Me}} \ldots \mathrm{M}^{\prime}-\mathrm{D}^{\prime}
$$

Onde:

$\mathrm{D}$ = capital-dinheiro

Dl = gastos na compra de mercadorias

D2 = gastos de aquisição do plantel (6)

$\mathrm{M}$ = capital-mercadorias

$\mathrm{Me}=$ mercadorias destinadas ao sustento da escravaria (7)

$\mathrm{Mp}=$ meios de produção

$\mathrm{P}=$ capital produtivo

M' = capital-mercadorias, em termos concretos: mercadorias resultantes do processo produtivo

$\mathrm{D}^{\prime}$ = capital-dinheiro valorizado, ou seja: resultado da realização do preço de $\mathrm{M}^{\prime}$.

Sendo:

$$
\begin{aligned}
\mathrm{M}=\mathrm{Me}+\mathrm{Mp} & \\
\mathrm{D}=\mathrm{D} 1+\mathrm{D} 2 & \\
\mathrm{D}^{\prime}=\mathrm{D} 1+\mathrm{d} & \\
\mathrm{d}=\mathrm{D} 2+\mathrm{L} \text { onde: } \quad \mathrm{d}= & \text { mais-valia } \\
\mathrm{L}= & \begin{array}{l}
\text { lucro do escravista, líquido do } \\
\text { gasto de aquisição do plantel }(8) .
\end{array}
\end{aligned}
$$

Donde:

$$
\mathrm{D}^{\prime}=\mathrm{Dl}+\mathrm{D} 2+\mathrm{L}
$$

Visto em termos de seus estágios, o processo cíclico do capital escravista-mercantil não difere do apresentado por Marx para o capital industrial (9). Também em nosso caso podemos verificar a existência de três estágios bem definidos pelos quais passa o capital escravista-mercantil. 
No primeiro estágio:

$$
\mathrm{D}<\mathrm{Dl}-\mathrm{M}<\underset{\mathrm{Mp}}{\mathrm{Me}}
$$

o escravista surge como comprador de mercadorias destinadas ao processo produtivo. Nesse momento definem-se marcantes dissimilitudes relativamente ao capital industrial, as quais decorrem da especificidade do escravismo no que tange ao aliciamento da mão-de-obra.

O escravista, para dar início à produção e reproduzi-la nos períodos subseqüentes, obriga-se a destinar parcela do capital inicial (D) para a aquisição do plantel. Tal fração, representada por D2, indica o custo incorrido pelo escravista para ter à sua disposição a mão-de-obra de que carece. Para tanto ele terá de servir-se do mercado de escravos. Os negros apresados no continente africano e trazidos para a América ou os escravos já residentes na colônia e postos à venda por seus proprietários constituirão o lado da oferta. $\mathrm{O}$ assentamento da relação de escravidão tem como pressuposto básico a constituição de tal mercado, pois a simples necessidade desse tipo de trabalhador, ainda que conjugada com a disponibilidade de recursos, mostrar-seia insuficiente para consubstanciar tal relação de sujeição em bases estáveis e na amplitude necessária. Uma vez comprado, o escravo pode passar a constituir "parte integrante do capital produtivo de seu comprador" da mesma forma que a força de trabalho vendida ao capitalista pelo assalariado.

A parte restante do capital (Dl) destinar-se-á à compra e/ou manutenção dos equipamentos e instalações imprescindíveis à produção $(\mathrm{Mp})$ e aos dispêndios com habitação, vestuário e alimentação necessários para manter vivos e produtivos os escravos (Me). Aqui, ao invés de um pagamento monetário como ocorre no caso do assalariado, o escravista encarrega-se, ele mesmo, de prover as mercadorias destinadas ao sustento do trabalhador. A origem destes bens pode ser a oferta externa, européia sobretudo, ou mesmo a produção realizada no âmbito da colônia ou da própria unidade produtiva local.

No segundo estágio, o proprietário de escravos combina os elementos adquiridos no primeiro; mediante o consumo produtivo dos mesmos, gera-se um quantum de produto com valor superior ao do início do processo. Neste estágio produtivo - no qual aqueles elementos encontram-se "no estado ou na forma de capital produtivo" - cria-se valor suficiente para a 
reposição dos gastos com a depreciação dos meios de produção e com o sustento dos escravos e, ademais, gera-se a mais-valia.

A mais-valia gerada no processo produtivo do capital escravista-mercantil (d) deve ser capaz, portanto, de proporcionar não só o lucro líquido do escravista, mas também o montante de capital necessário para aquisição/reposição dos escravos (D2). Vale dizer, como Gorender, tratamos o dispêndio com a aquisição do plantel como uma dedução da mais-valia total.

Todavia, sem a realização das mercadorias, isto é, sem o terceiro estágio ( M' - D'), não poderia se dar o prosseguimento do processo produtivo. Faz-se mister, portanto, que o capital-mercadoria assuma a forma de capital-dinheiro ao final do processo para poder ingressar novamente no ciclo de valorização. Apenas como capital-monetário, o capital assume a forma de "meio geral de compra e meio geral de pagamento", tornando-se capaz de agenciar elementos para o ciclo produtivo subseqüente.

\section{Causas históricas da superação \\ do capital escravista-mercantil}

Como tivemos oportunidade de consignar acima, o capital escravistamercantil devia sua reprodução a algumas condições que lhe eram imanentes e a outras que, para ele, definiam-se como dadas, pois independiam de sua existência e situavam-se no âmbito da economia mundial: mercados fornecedores de mão-de-obra cativa e mercados absorvedores da produção exportável ofertada pela economia escravista. A estas últimas, somavam-se, pois, as condições de ordem endógena: institucionalização do escravismo, escravistas desejosos de acumular e a massa de cativos disponível internamente. Como avançado, as condições exógenas fugiam à ação imediata do capital escravista-mercantil cuja supressão, portanto, poderia advir de um ou mais eventos originados na órbita externa, na interna, ou colocados numa ou noutra dessas esferas, pois, a falta de qualquer pressuposto, endógeno ou exógeno, seria bastante para provocar sua ruptura.

A conseqüência mais significativa dessas características está em que, por ser incapaz de reproduzir integralmente suas próprias condições de existência, o capital escravista-mercantil não podia, pois, dar suporte a um específico modo de produção. Destarte, o lapso temporal de sua dominância em dada área ou nação deve ser tomado - por mais longo que se apresente - como um período de transição.

No caso do escravismo moderno tratou-se efetivamente da incorporação, à economia mundial já fortemente impregnada pelo capitalismo, de 
terras praticamente virgens ou de áreas mais densamente povoadas cujos autóctones conheceram um total derruimento do destino que lhes era traçado pelas formas de existência social, econômica e política sob as quais viviam antes da chegada do colonizador europeu. No que tange ao Novo Mundo, tal transição culminou com a transformação radical das relações de produção - de escravistas para capitalistas - e a correlata metamorfose do capital escravista-mercantil em capital industrial, vale dizer: em acumulação calcada na exploração da mão-de-obra assalariada.

Além disso, à medida que no âmbito das sociedades escravistas modernas foram, a pouco e pouco, se consubstanciando as condições para o estabelecimento generalizado do trabalho assalariado, a transição para estas relações de produção - inclusive com a presença de formas de exploração do trabalho livre como os contratos de parceria, de locação de serviços e o sistema do colonato, adotados no Brasil - não assumiu, do ponto de vista estritamente econômico, caráter traumático, dando-se o mesmo com respeito à transformação do capital escravista-mercantil em capital industrial. Destarte, as mudanças havidas não decorreram de uma revolução burguesa no sentido clássico da expressão, mas devem ser definidas como duas facetas de um processo único: o da superação do escravismo. Processo no bojo do qual atuaram de maneira solidária e integrada - com pesos relativos distintos, é verdade - fatores de caráter político, social e econômico.

Note-se, ainda, que a solidez ou robustez do escravismo, bem como a coesão interna de dada sociedade escravista, não bastavam, per se, para garantir a subsistência do capital escravista-mercantil, pois, como já afirmado, a presença de tais atributos só era relevante para a manutenção dos determinantes de ordem endógena desta específica forma de existência do capital.

Do exposto, conclui-se que o estudo da supressão do capital escravistamercantil se confunde com o da abolição do escravismo. Assim - e aqui falamos em termos hipotéticos e não-exaustivos -, o golpe mortal contra o capital escravista-mercantil (ou contra o escravismo), nesta ou naquela área e/ou nação, poderia decorrer de uma, ou da combinação de duas ou mais, das seguintes causas imediatas:

- imposição da metrópole com respeito a suas dependências coloniais;

- imposição de nação estrangeira em decorrência de atritos econômicos e/ou armados;

- decisão política adotada de maneira unânime pelas próprias elites escravistas dominantes ou decorrente de uma cisão no corpo das mes- 
mas de sorte a levar a um confronto entre as facções discordantes do qual, no caso, sairia vencedora a ala favorável à abolição;

- sublevação dos cativos;

- uma forte expansão da demanda internacional por tal ou qual bem produzido por dada economia escravista poderia levá-la a encontrar tamanhas restrições quanto ao aliciamento de mão-de-obra cativa que a busca de uma alternativa não-escravista se impusesse;

- correlativamente, a retração violenta dos mercados mundiais para os bens oferecidos por dada economia escravista poderia levá-la, no médio prazo, ao colapso, pois faltar-lhe-iam os recursos para sustentar-se enquanto tal;

- a supressão do tráfico também conduziria, na falta de uma oferta interna renovável de cativos (10), inexoravelmente, ao desaparecimento, em prazo mais ou menos dilatado, do capital escravista-mercantil.

Examinemos mais de perto algumas situações concretas nas quais podem ser identificadas algumas das causas acima aventadas. No que concerne a alguns países da América do Sul, houve, segundo Donghi, uma influência decisiva das guerras de independência na conformação e no ritmo do processo de abolição da escravatura. Com efeito, a partir dos conflitos armados a caracterizar a luta pela independência comandada por Bolívar e San Martín “o significado da escravidão se modificou: embora os novos Estados não se demonstrem dispostos a aboli-la (escolhem, ao contrário, situações de compromisso, como a proibição do comércio e a liberdade para os filhos dos escravos, inovações de alcance mais limitado do que poderia parecer), a guerra os induz a emancipações cada vez mais amplas; e as guerras civis serão ocasião de novos passos nessa direção (...) A emancipação tem a finalidade de recrutar soldados; e, além desse objetivo imediato, em alguns casos se busca explicitamente conservar o equilíbrio racial, garantindo que também os negros forneçam a sua cota de mortos em combate. É esse o argumento de Bolívar em apoio às providências que tomou, e que não eram aceitas pelos proprietários de escravos. A escravidão doméstica perde importância, enquanto a agrícola resiste melhor nas zonas das plantações, que não poderiam sobreviver sem ela. Ainda em 1827, sua importância na Venezuela é tão grande que justifica uma tenaz defesa por parte dos latifundiários. Onde a escravidão se conserva, a disciplina da mão-de-obra escrava perde boa parte da sua eficiência. A produtividade cai na Venezuela e na costa do Peru (e aqui de modo catastrófico), o mesmo ocorrendo nas zonas mineradoras de Nova Granada, nas quais se empregava mão-de-obra africana” (Donghi, 1975:83-84). 
Ademais, o fim do tráfico de escravos e o impacto dessa medida sobre o mercado de escravos implicou a inviabilização econômica cada vez maior das atividades assentadas na mão-de-obra cativa. "A implantação e substituição da mão-de-obra coloca problemas; a longo prazo, a escravidão não consegue sobreviver na América espanhola sem o tráfico; e, com as crescentes dificuldades do mercado, o preço dos escravos - onde eles são empregados em atividades produtivas - cresce rapidamente; ao longo da costa peruana, durante a década posterior à revolução, o seu preço triplica. O instituto da escravidão, antes de ser abolido (quase por toda parte na metade do século) perde importância. Os negros emancipados não serão reconhecidos como iguais à população branca e nem mesmo à mestiça; mas a posição deles será profundamente diferente numa sociedade que, se não é igualitária, organiza porém as desigualdades de um modo diverso da velha sociedade colonial" (Donghi, 1975:83-84).

Detenhamo-nos agora em alguns processos de emancipação verificados em outros países e regiões da América, para os quais a importância da escravidão e a literatura disponível se mostraram bem mais significativas.

\section{O Haiti e a rebelião negra}

Segundo país do continente a tornar-se independente após os Estados Unidos, a parte ocidental da Ilha de Hispaniola, no Caribe, contava, às vésperas da Revolução, com cerca de 550 mil habitantes, $80 \%$ dos quais escravos (Cf. Cardoso \& Brignoli, 1983:147). A vida econômica e política do Haiti era monopolizada por uma elite reduzida de brancos e mulatos, impedindo-se de forma definitiva a ocupação de cargos públicos e profissões liberais por parte de negros, mesmo se libertos. Como sabido, a base econômica principal do Haiti era a produção de açúcar, seguida de café, anil e algodão.

As revoltas - iniciadas em $1758 \mathrm{sob}$ a liderança de Makandal e sufocadas em sua maior parte - retornaram no outono de 1791 com amplitude revolucionária, envolvendo praticamente todo o território haitiano. Os escravos rebelados incendiaram os canaviais e expulsaram os exércitos franceses. Com a vitória sobre as forças francesas, François Toussaint, também conhecido como Toussaint Louverture, proclamou a independência e a libertação dos escravos, mantendo-se, todavia, dentro da federação francesa.

Ainda durante o processo de consolidação do novo poder político, a crise e o bloqueio econômico imposto pela França que se seguiram à guerra de independência condicionaram fortemente a política de Toussaint relativamente à mão-de-obra. Foi instituído "um rígido sistema de trabalho for- 
çado, anulando vendas de terras anteriores para trabalhadores rurais e sujeitando os trabalhadores das fazendas a uma disciplina militar" (Foner, 1988:29). Tais imposições decorriam de uma tentativa de não isolar política e economicamente o Haiti do restante do mundo (11), bem como de estabelecer uma política conciliatória com os fazendeiros brancos, uma vez que a grande propriedade rural voltada à exportação era encarada como a chave da prosperidade para o país.

Apesar de demonstrar esse tipo de preocupação, Toussaint foi derrotado por Charles Leclerc - cunhado de Napoleão - em 1803, e enviado para a França onde é executado.

Jean-Jacques Dessalines assume então a liderança na luta dos haitianos e consegue expulsar novamente os franceses, criando a segunda república do Hemisfério Ocidental em 1806. Com a ascensão ao poder de Dessalines, a política conciliatória de Toussaint com relação aos fazendeiros foi drasticamente abandonada - tendo sido massacrados os brancos remanescentes e incorporadas suas fazendas ao patrimônio do Estado. Entretanto, a crença de Dessalines de que apenas a agricultura de exportação seria capaz de garantir a manutenção de um exército forte e, desta forma, consolidar a independência da nação, levou-o a preservar a política de trabalho forçado, a qual não diferia muito da escravidão, inclusive por empregar o açoite como medida disciplinadora (Cf. Foner, 1988:29).

Tal legislação punitiva e rigorosa quanto à obrigação de trabalhar manteve-se, com pequenas alterações, nos governos seguintes, suplantada porém ao longo do século XIX pela emergência do campesinato haitiano, mediante a ampliação do acesso à propriedade da terra (12).

\section{As Antilhas e a presença metropolitana}

O fim da escravidão nas Antilhas e Guianas decorreu, imediatamente, de decisões tomadas no âmbito das metrópoles às quais se encontravam subordinadas essas áreas. No caso das colônias administradas diretamente pela Coroa inglesa, a legislação referente à emancipação por estágios foi imposta diretamente, tendo sido negociada quando a colônia tinha legislação própria (Cf. Craton, 1995:46).

O processo que levou à emancipação dos negros nas colônias inglesas na América (13) - iniciado a partir da proibição do tráfico britânico de escravos da África em 1808 - foi radicalmente distinto daquele observado no Haiti, como ver-se-á mais adiante. "Se no Haiti a abolição se realizou através da revolução, no Caribe inglês o processo refletiu tudo o que é 
quintessencialmente inglês: respeito pela ordem, processos legais e direitos de propriedade" (14) Foner, 1988:33).

A manumissão nas possessões britânicas caracterizou-se, sobretudo, pela intenção de gerar o menor atrito possível com a classe de proprietários de escravos; buscou-se preservar em suas mãos tanto a propriedade da terra quanto o poder político. Ademais, o governo inglês indenizou os antigos donos de escravos com $£ 20$ milhões (Cf. Foner, 1988:33). Inicialmente, as autoridades britânicas buscaram - mediante a instituição do aprendizado uma solução conciliatória entre, de um lado, a opinião pública antiescravocrata e seu próprio compromisso público com a idéia do trabalho livre e, de outro, os interesses da classe de proprietários de escravos. Também pesou, na decisão de estabelecer o aprendizado, a desconfiança relativamente ao comportamento do manumitido. Segundo a lei de 1833, "todos os escravos na lavoura serviriam por seis anos como aprendizes, período durante o qual seriam pagos por seus trabalhos, permanecendo, porém, sujeitos a regulamentações severas determinadas pelas legislaturas coloniais" (Foner, 1988:36). Pretendia-se, dessa maneira, assegurar um processo de transição o menos traumático possível entre a escravatura e o trabalho livre.

O resultado de tal tentativa foi um fracasso evidente. Um dos principais problemas de que se revestiu o aprendizado foi o fato de o governo inglês deixar as regulamentações pertinentes a cargo das assembléias locais, dominadas pelos grandes proprietários. As penas extremamente severas impostas pelos legisladores caribenhos aos menores deslizes e resistência ao trabalho por parte dos ex-escravos, as quais "cheiravam em excesso a um retorno da escravidão" (Foner, 1988:38), fizeram com que as autoridades britânicas - pressionadas por uma opinião pública desfavorável ao aprendizado - impusessem o fim ao experimento, decretando a liberdade incondicional dos aprendizes em 1838 (Cf. Foner, 1988:38-39).

Nas demais colônias européias do Caribe o processo foi também definido a partir de decisões tomadas nos respectivos centros metropolitanos. "Depois de medidas parciais, os franceses aboliram a escravidão em 1848, tendo a revolução daquele ano agido como catalisador. A Holanda, também depois de medidas parciais, protelou até 1863 a abolição final" (Cardoso \& Brignoli, 1983:150). É importante notar que também nestes casos a decisão dos países europeus foi acompanhada de compensação monetária aos proprietários dos escravos manumitidos, tendo sido facilitada, ademais, pelo fato de tais proprietários constituírem uma parcela restrita das burguesias metropolitanas. Assinale-se, também, que as feições genéricas, apontadas, assumidas pelo processo de abolição do trabalho escravo nas referidas 
dependências coloniais não comporta qualquer dúvida; a polêmica existente - e ela foge ao escopo deste artigo - diz respeito às razões associadas ao interesse pelo fim do tráfico e da escravidão por parte das potências européias, notadamente no que se refere à Inglaterra (15).

Outros fatores, e não apenas os relacionados aos interesses e disputas internas às Metrópoles, devem, no entanto, ser agregados. Entre eles destaca-se o exemplo haitiano e a eclosão freqüente de revoltas de escravos em toda região, as quais amedrontavam tanto as autoridades metropolitanas quanto os proprietários locais, impelindo-os a vislumbrarem na manumissão geral uma alternativa menos ruim. No caso das possessões britânicas na América cabe citar as rebeliões de escravos ocorridas em Barbados (1816), Guiana Inglesa (1823) e Jamaica (1831-32) (Cf. Craton, 1995:32-33).

\section{Nos Estados Unidos, a dissensão das elites}

Em contraste com o processo lento, gradual e contemporizador que caracterizou a extinção do escravismo em Cuba e no Brasil, nos Estados Unidos tal evento ocorreu de forma abrupta, como resultado de um violento conflito armado. A emancipação nos Estados Unidos - a qual englobou número muito superior de pessoas do que o observado em qualquer outro país ou colônia, cerca de 4 milhões - resultou, à semelhança do ocorrido no Haiti, de uma guerra sangrenta, na qual os negros tiveram participação expressiva (Cf. Foner, 1988:73).

Os principais fatos históricos que antecederam imediatamente o término do regime escravista são conhecidos: a eleição de Abraham Lincoln, em 1860, pelo Partido Republicano; a decretação da emancipação; a oposição dos estados sulistas, a tentativa de Secessão e o início da Guerra Civil; a vitória da União ratificada em 1865 e a consagração do abolicionismo.

Para os efeitos deste artigo, os pontos importantes a serem realçados dizem respeito aos motivos da guerra e aos interesses divergentes do Norte e do Sul quanto à escravidão (16).

Em primeiro lugar cabe destacar a reduzida relevância das análises que se concentram de forma exclusiva nos fatores de ordem econômica, como, por exemplo, na questão das tarifas de importação ou na suposta incompatibilidade econômica entre a mão-de-obra escrava e o crescente capitalismo industrial.

Na verdade, como demonstra Moore Jr., no período 1815-1860 a economia algodoeira do Sul exerceu influência decisiva no crescimento da 
economia norte-americana e, até 1830 , constituiu o fator mais importante do desenvolvimento industrial nortista. Ademais, devido ao expressivo volume de exportações para a Grã-Bretanha, responsabilizava-se pela parcela principal da oferta de divisas. Portanto, longe de se caracterizar como excrescência, a economia escravista revelou-se parte integrante da formação do capitalismo industrial do século XIX.

Do mesmo modo cabe rejeitar as teses que atribuem ao sistema escravista um tal nível de ineficiência vis-à-vis o trabalho assalariado que o condenaria a desaparecer. Os estudos mais recentes mostram que a escravatura não estava prestes a se extinguir por razões internas, pois, do ponto de vista econômico, ainda evidenciava boas condições de competitividade e lucratividade. Nesse sentido, a força das armas mostrou-se fundamental para pôr fim à escravidão nos Estados Unidos.

Conquanto os fatores estritamente econômicos tenham certo poder explicativo, parecem-nos secundários frente às divergências políticas, sociais e ideológicas existentes entre o Norte e o Sul. Ou, colocando de forma mais precisa, embora a origem essencial da diferenciação entre as duas sociedades situe-se no campo econômico - dada pela relação de produção hegemônica diversa a caracterizar cada uma das duas regiões - a Guerra de Secessão encontra-se, na realidade, relacionada às dificuldades de convivência, sob um mesmo governo nacional, de duas sociedades com características tão distintas, conquanto capitalistas: uma, aristocrática, defensora do privilégio hereditário e a outra, burguesa, valorizadora do esforço e talento individual e contrária à desigualdade jurídica e de oportunidades (17). "Com o Oeste, o Norte criou uma sociedade e uma cultura cujos valores entraram cada vez mais em conflito com os do Sul. O ponto focal dessas diferenças residia na escravatura" (Moore Jr., 1975:169).

Face a tal quadro, tornou-se cada vez mais improvável - para ventura da democracia norte-americana - a solução conciliatória entre a burguesia industrial e as elites rurais, típica da Alemanha do século XIX.

A busca desta solução fez-se em vão na primeira metade do século. Alguns anos após o fim do tráfico de escravos (1808) (Cf. Foner, 1988:130), tentou-se instituir uma fórmula para manter o equilíbrio entre os estados escravistas e abolicionistas. Por meio do “Compromisso de Missouri” (1820) ficou estabelecido que os estados ao norte do paralelo $36^{\circ} 30^{\prime}$ seriam emancipacionistas e, escravistas, os colocados ao sul de tal linha. No entanto, em 1850, a Califórnia solicita sua entrada na União como estado abolicionista, apesar de se situar ao sul daquele paralelo. Houve protestos dos estados escravistas, sendo, por fim, acordado o denominado "Compromisso de 
1850", assegurando o livre arbítrio dos novos estados quanto à escravidão. Tal solução, entretanto, parece não ter sido satisfatória, pois o problema da escravatura nos territórios desempenhou papel crucial para conduzir à guerra.

Tratava-se, dentre outras questões, de definir a que interesses/conveniências o Governo Central iria se colocar à disposição. "O aspecto fundamental tornou-se cada vez mais o fato de a maquinaria do governo federal dever ser usada para apoiar uma sociedade ou a outra. Era esse o significado por trás de assuntos tão pouco interessantes como a tarifa alfandegária e que pôs paixão na reclamação sulista, ao afirmar que estava a pagar tributo ao Norte. A questão do poder central tornou também crucial a questão da escravatura nos territórios. Os dirigentes políticos sabiam que a admissão de um estado de escravos ou de um estado de trabalhadores livres desequilibraria a balança para um lado ou para o outro. $\mathrm{O}$ fato de a incerteza constituir parte inerente da situação, devido às terras não-colonizadas, ou parcialmente colonizadas, do Oeste, aumentou muito as dificuldades para se chegar a um compromisso. Cada vez mais se tornou necessário que os dirigentes políticos de ambos os lados se mantivessem em alerta para qualquer movimento que pudesse aumentar as vantagens do outro. Dentro deste contexto maior, a tese da tentativa de veto do Sul ao progresso nortista faz sentido, como causa importante para a guerra" (Moore Jr., 1975:169).

A vitória do Norte, como sabido, permitiu definir tal disputa de forma favorável aos interesses industriais e consolidar a emancipação dos escravos. Todavia, a derrota dos republicanos radicais - os quais propunham reformas profundas na estrutura econômica e política do Sul -, ao longo da década de 1870, obstou a consecução de melhorias significativas no padrão de vida dos libertos (18).

\section{Em Cuba: um caminho longo e complexo}

A supressão do escravismo em Cuba lembra, em linhas gerais, a experiência observada no Brasil. Trata-se de um processo gradual no qual intervieram vários fatores, tanto de ordem interna como externa.

Cardoso \& Brignoli identificam duas grandes fases no processo de abolição da escravidão em Cuba. A primeira estende-se do início da década de 1840 até o começo da Guerra dos Dez Anos em 1868. A segunda fase compreende o período da guerra de libertação (1868-78) e se estende até 1886, com o fim definitivo da escravidão dada a extinção do patronato (Cardoso \& Brignoli, 1983:150-153). Em 1845, por conta dos movimentos e conspirações de escravos ocorridos entre 1841 e 1843 e da pressão diplomática e naval da Inglaterra, a Espanha elaborou a lei de abolição e 
repressão do tráfico de escravos, cujo objetivo fundamental seria propiciar instrumentos mais adequados à repressão do tráfico, já ilegal havia muitos anos (19). Tal legislação apresentou alguma efetividade durante a década de 40, quando se reduziu o número de escravos desembarcados na Ilha, voltando porém a aumentar na década seguinte o contingente de negros provindos da África, apesar de a manutenção das imposições inglesas. O tráfico só cessou, de fato, em meados da década de 60; é importante notar, no que tange a tal aspecto, a existência de um grupo de escravistas interessado em, simultaneamente, pôr termo ao tráfico e manter a escravidão, com o intuito de valorizar o estoque de escravos em seu poder.

Nos marcos desta primeira fase deu-se, ainda, a Guerra de Secessão nos Estados Unidos e o enfraquecimento da causa escravista em todo o continente em decorrência da abolição que se seguiu à vitória do Norte sobre o Sul.

O início da Guerra dos Dez Anos, em 1868, marca um momento de inflexão no processo abolicionista, o qual se acelera a partir de então. Em 1869 os rebeldes cubanos, que lutavam pela independência da Ilha, tendo em vista a pressão interna de suas próprias fileiras de soldados - compostas em grande parte por libertos - e a necessidade de apoio internacional para a causa, abandonam sua posição reticente quanto ao fim da escravidão e propõem a emancipação imediata dos escravos. A libertação plena, no entanto, viu-se obstada pelo Reglamento de Libertos, o qual exigia trabalho forçado dos ex-escravos. Apenas com o abandono do Reglamento, no final de 1870, é que os rebeldes assumiram definitivamente a causa dos escravos (Scott, 1987:458). Desse modo, conquanto de início limitados em seus ímpetos abolicionistas, os revolucionários cubanos foram compelidos pelas circunstâncias a comprometerem-se cada vez mais com o fim da escravidão: “o impacto da insurreição sobre a escravidão ultrapassou a intenção inicial de seus líderes. A própria política rebelde foi pressionada a desenvolver-se em direção a um abolicionismo menos limitado, especialmente à medida que cresceu a participação de pessoas de cor livres e de libertos no exército. Ao mesmo tempo, os libertos aprenderam a aproveitar-se até mesmo de concessões parciais e oportunistas feitas pelos líderes rebeldes” (Scott, 1987:460).

A resposta do lado espanhol não tardou; frente aos interesses divergentes de abolicionistas cubanos - aos quais poderiam vir a se aliar os norteamericanos - de um lado, e de senhores de engenho por outro, as Cortes Espanholas aprovaram a Lei Moret, a qual apontava para uma "solução conciliatória”, mediante a proposta de extinção gradual da escravidão. Os escravos acima de 60 anos e as crianças nascidas a partir de 1868 teriam sua 
liberdade assegurada, conquanto, estas últimas, ainda devessem permanecer sob a "proteção" de seus ex-donos até que se casassem ou completassem 21 anos de idade. Além disso, tal legislação tornava ilegal o açoite e libertava o escravo vítima comprovada de "crueldade excessiva", estabelecendo também as "Juntas Protectoras de Libertos" para vigiar o cumprimento da lei. Previa, ademais, a emancipação indenizada ao final da Guerra (Scott, 1987:461).

Apesar de a constatação de fraudes de variados tipos - notadamente no que diz respeito ao estabelecimento da idade e da data de nascimento dos escravos - e a obrigação do patronato até a maioridade para os recémnascidos tornarem a lei muito menos efetiva do que poderia parecer à primeira vista, a existência de tal legislação e a insurreição constituíram poderoso estímulo para que os escravos buscassem concessões cada vez maiores. "A conjuntura da década de 1870, com o aparato legal para o eventual fim da escravidão e o surto revolucionário no leste, encorajou alguns escravos a pressionar por quaisquer concessões que pudessem obter. Para tanto eles fizeram uso de velhas e novas técnicas" (Scott, 1985:74).

Tal situação foi deveras reforçada pelos acontecimentos posteriores ao fim da Guerra dos Dez Anos. O Pacto de Zanjón, de 1878, que pôs fim ao conflito, garantiu a liberdade a "todos os escravos e asiáticos que tivessem lutado pela independência ou contra ela" (Cardoso \& Brignoli, 1983:152), fato que, por certo, contribuiu para o crescimento da resistência passiva, das ameaças de sublevação e das fugas em massa dos escravos, como as ocorridas na província de Santiago de Cuba nos anos finais da década de 1870 , as quais obrigavam os plantadores a fazerem concessões, sob pena de perderem o controle sobre a mão-de-obra, mesmo contando com o apoio militar. É nesse contexto que "em 1879 o governo espanhol preparou uma lei abolicionista final, posta em vigor no dia 29 de julho de 1880. Ela decidia a abolição total, mas estendia o patronato a todos os novos libertos, em lugar de uma indenização pecuniária aos proprietários. Tal patronato terminaria em 1888" (Cardoso \& Brignoli, 1983:153). Sob a "retórica da tutelagem e proteção" (Scott, 1987:466) pretendia-se manter as relações fundamentais da escravidão, alterando-se apenas aspectos relacionados à sua aparência. Os ex-escravos, agora patrocinados, a par de alguns direitos alcançados, viam-se na obrigação de trabalhar por um salário simbólico, não podendo sair da propriedade de seu dono ou escolher seu patrão e sendo objeto de compra e venda como anteriormente.

Todavia, os resultados finais da nova legislação parecem ter sido mais significativos do que os inicialmente pretendidos. As iniciativas dos patroci- 
nados - as quais poderíamos caracterizar como um ponto intermediário entre a acomodação e a resistência (20) - implicavam a aceitação da ordem legal escravista, exploravam as possibilidades de libertação colocadas pela nova ordem legal, notadamente no que diz respeito à autocompra e às denúncias de abusos, violências e ausência de cuidados legalmente previstos por parte do patrono (21). O patrocinato permitiu aos escravos influenciar o ritmo em que se alteravam as relações de produção fundamentais, até mesmo no que diz respeito ao seu conteúdo, chegando-se à própria manumissão. Assim, tais expedientes permitiram que o número de escravos existentes em Cuba às vésperas do fim do patronato (1886) fosse pouco superior a $25 \mathrm{mil}$, número quase oito vezes menor do que o existente nove anos antes. A verdade é que "em um contexto de hostilidade internacional para com a escravidão, de contínuos desafios ao domínio espanhol e crescente percepção das vítimas do escravismo de que o sistema não sobreviveria por muito tempo, a legislação não pôde refrear as pressões por mudanças mais rápidas" (Scott, 1987:484).

Destarte, com o declínio dos preços do açúcar no mercado internacional a partir de 1885 e o conseqüente rebaixamento da lucratividade da atividade açucareira, diluíram-se as resistências mais importantes ao fim da escravidão. Assim, em julho de 1886, o parlamento espanhol votou a autorização para a extinção do patronato e, no mês seguinte, a Junta Provincial de Agricultura, Indústria e Comércio de Havana concordou com tal resolução (Scott, 1987:482). Em 7 de outubro de 1886, dois anos antes do prazo fixado pela lei de 1880, o patronato foi suprimido, encerrando-se a escravidão na maior ilha das Antilhas.

\section{A intervenção estrangeira no Paraguai}

No Paraguai, como sabido, o término do escravismo decorreu da intervenção de potências estrangeiras no âmbito da guerra no qual aquela nação viu-se derrotada pela Tríplice Aliança formada por Brasil, Argentina e Uruguai. Assim, coube ao conde D'Eu, comandante das tropas brasileiras, libertar os últimos escravos existentes na nação perdedora. Materializou-se neste caso, independentemente das motivações últimas das tropas de ocupação e de seus respectivos governos, a possibilidade de superação da ordem escravista em função de intervenção militar externa.

\section{O caso do Brasil: conjugação de fatores externos e internos}

O fim da escravidão no Brasil emergiu como resultado de diversos condicionantes internos e externos. 
Em primeiro lugar, ressalta-se a participação destacada na Inglaterra no que tange ao término do comércio de escravos. A desagregação do sistema escravista brasileiro inicia-se, de fato, com o fim do tráfico, em 1850, por conta, sobretudo, da pressão inglesa (22). As tentativas da Inglaterra em fazer cessar o fluxo de negros da África para a América - cujas motivações fundamentais parecem ter sido de ordem humanitária e econômica, não cabendo aqui a discussão a respeito da importância relativa de cada um desses fatores - foram decisivas para, no mínimo, antecipar tal decisão por parte do governo brasileiro, o qual resistiu obstinadamente às investidas inglesas contra o tráfico realizadas desde os Tratados de 1810.

A incapacidade de reprodução vegetativa da população escrava, a menor taxa de natalidade $v i s-\grave{a}$-vis a taxa de mortalidade dos escravos condenava inexoravelmente o sistema escravista a seu término.

Somou-se a este fator o grande desenvolvimento da economia cafeeira, o que determinou uma significativa escassez relativa de mão-de-obra. É justamente na segunda metade do século XIX que a economia cafeeira apresenta suas mais expressivas taxas de crescimento. As condições favoráveis de solo e clima, a grande disponibilidade de terras para serem ocupadas e o expressivo crescimento da demanda mundial - norte-americana, sobretudo - permitiram consolidar de vez o café como nosso principal produto de exportação. Restava solucionar o problema da mão-de-obra. Vislumbradas as possibilidades restritas do comércio interno de escravos e da utilização da mão-de-obra livre nacional para atender à demanda ascendente de trabalhadores braçais, a opção fez-se em favor da política imigrantista, opção favorecida pelas condições prevalecentes na Europa, as quais se responsabilizavam por expulsar enormes contingentes de trabalhadores.

A constituição, por esse meio, do mercado de trabalho livre no Brasil, somada ao encarecimento do preço do escravo, permitiu tornar cada vez menos importante a mão-de-obra escrava, notadamente nas regiões cafeeiras mais dinâmicas, como o oeste paulista. No entanto, alguns grupos de interesses econômicos fortemente fundados na escravidão ainda resistiam, obstaculizando e tornando muito lento o processo de abolição que se arrastou ao longo das décadas de 60 a 80 do século passado sob a forma de concessões tópicas, como a Lei dos Sexagenários e do Ventre Livre, cuja efetividade mostrou-se muito discutível.

Nesse sentido, houve uma divisão crescente no seio da elite dominante quanto à questão escravista. Segundo Beiguelman (1977), a opção dos fazendeiros do oeste paulista pelo abolicionismo faz-se tendo em vista a oposição dos fazendeiros escravistas, notadamente do Vale do Paraíba à política 
imigrantista, obrigando a tomada de posição por parte dos primeiros em favor do fim da escravidão como forma de consolidação da política imigrantista. Além disso também há de se considerar o desequilíbrio na proporção de escravos entre o Norte/Nordeste e o Sudeste. A reduzida magnitude do número de escravos contribuiu para que a resistência política ao fim da escravidão naquelas regiões fosse praticamente nula na década de 80 .

Tais fatos, somados à importância cada vez maior do movimento abolicionista e da resistência dos próprios escravos mostraram-se fundamentais para dar um paradeiro ao escravismo no Brasil.

\section{Considerações finais}

Cremos que, além de evidenciar a pertinência e a relevância do conceito, explicitamos algumas das principais propriedades do capital escravistamercantil, e algumas das implicações decorrentes da existência dessa forma específica de valorização do valor. Acreditamos, igualmente, haver mostrado que muito do que se afirma sobre o modo de produção escravista referese, de fato, à forma de capital aqui postulada. Assim, tanto a economia escravista moderna quanto muitas das sociedades estabelecidas no Novo Mundo devem sua existência e conformação estrutural básica ao capital escravista-mercantil, não podendo ser vistas, portanto, nem como mera projeção do capital comercial no plano da produção, nem como simples apêndice da economia européia, destinado, exclusivamente, a complementá-la e a servir tão-somente a interesses forâneos. Não é ocioso repisar que a falta da consideração do capital escravista-mercantil leva ao falseamento da natureza e do caráter essencial das economias e das sociedades estabelecidas nas Américas.

De outra parte, as distintas maneiras assumidas pelo término da escravidão nas Américas cobrem, em larga medida, as formas hipotéticas aventadas na abertura do tópico "causas históricas da superação do capital escravistamercantil”.

Ademais, tais formas de superação do escravismo moderno definemse como elementos que, a par de outros, corroboram nossa tese sobre à existência de uma peculiar forma de capital - categoria esta não explorada por Marx - e à qual emprestamos a denominação de capital escravista-mercantil. Cumpre-nos, por fim, chamar a atenção dos estudiosos para a necessidade de explorarmos criticamente essa eventual forma de existência do capital e suas implicações no que tange à formação econômica e social do mundo americano. 
Permanece, pois, a exigência de nos empenharmos no estudo das causas de fundo que determinaram, por um lado, a emergência e, de outro, a superação do capital escravista-mercantil. Sem o pleno conhecimento de tais fatores essa categoria permanecerá, apenas, como mais uma tentativa de explicação lógica para uma larga fase da história do colonialismo e do escravismo modernos ainda não totalmente dominada pela historiografia. É este, pois, o repto que lançamos a todos os pesquisadores que, como nós, entendem estarmos em face de uma questão ainda não resolvida.

Notas

1 Sobre o termo escravismo colonial veja-se Gorender (1992:157 e ss.). Diga-se, ademais, que, embora não tomemos o escravismo colonial como um modo de produção como o fez Gorender, concordamos em larga medida com suas percucientes análises.

2 Acreditamos que Barros de Castro tenha chegado muito próximo do estabelecimento da categoria capital escravista-mercantil. Sem comprometê-lo com nossa formulação, permitimo-nos entrevê-la na citação que segue: "O processo de trabalho num engenho escravista do século XVI é similar ao de uma grande lavoura plantation capitalista contemporânea. Além disso, mais se assemelha ao processo de trabalho numa grande fábrica inglesa do início do século XIX, que o [processo de trabalho] característico dos séculos XVI e XVII na Europa. Conseqüentemente, é lícito afirmar que, inserido no processo de produção material, o escravo constitui uma antecipação do moderno proletário. Por outro lado, o senhor do engenho encontra-se absorvido numa engrenagem que determina o seu comportamento, em função de 'necessidades' que nada têm a ver com as suas próprias vontades e necessidades pessoais. Estas características indicam, em suma, que o moderno escravismo tem importantes traços em comum com o capitalismo e, mais, que estas características pertencem à sua conformação interior. Não é, pois, necessário recorrer às conexões 'externas' - e muito menos a um simples 'critério de mercado' - para deixar assinaladas as fortes similitudes existentes entre o moderno escravismo e o capitalismo - proximidade esta que pode ainda ser realçada, ao lembrarmos que a organização produtiva aqui focalizada surge associada aos primórdios do capitalismo, cresce e se multiplica acoplada a ele" (grifos de Castro, 1980:92-93). Gorender, por seu turno, embora tenha observado a presença do capital no âmbito do escravismo colonial, não chegou às mesmas conclusões a que fomos levados; isto se deveu, a nosso ver, ao fato de esse autor haver privilegiado a categoria modo de produção escravista colonial: "Dado seu caráter mercantil, o escravismo colonial encerra categorias como as de mercadoria, dinheiro e capital - categorias adaptadas, todavia, a uma estrutura essencialmente distinta daquela inerente ao modo de produção capitalista. $\mathrm{O}$ escravismo colonial possui leis específicas, cuja atuação não teria qualquer razão de ser sob a vigência do capitalismo" (Gorender, 1983:13). 
3 Com respeito a este ponto também podemos contar com a esclarecedora interpretação de Gorender: "O escravismo colonial só possibilita um mercado interno estreito, pouco elástico, inadequado aos fins da produção mercantil, que tende à especialização. Mas este problema estava de antemão resolvido, pois sua solução constituía uma das premissas da criação da plantagem colonial. A produção desta última se escoaria no mercado externo já existente e em ampliação, com uma demanda crescente de gêneros tropicais - o mercado da Europa" (grifo de Gorender, 1992:163). Mais adiante acrescenta o autor: "Estavam criadas as condições objetivas para que o escravismo mercantil assumisse a única forma em que pode se desenvolver com amplitude: a forma de escravismo colonial, isto é, de um modo de produção dependente do mercado metropolitano. (...) O escravismo colonial não comportava a mercantilização total, pois subsiste nele um setor de economia natural, porém o comércio intensificado não exerce efeito desagregador na sua estrutura. $\mathrm{O}$ escravismo colonial nasce e se desenvolve com o mercado como sua atmosfera vital. A explicação já se contém no exposto acima: um modo de produção baseado na escravidão é compatível com a finalidade mercantil se estiver conjugado a um mercado externo apropriado. A existência prévia do mercado externo constitui, portanto, premissa incondicional" (grifos de Gorender, 1992:163-164).

4 Deve-se notar que Caio Prado Júnior prendeu-se, sobretudo, à forma como a valorização das novas terras aparece ao observador que a toma da perspectiva do comércio externo, não levando em conta a existência do capital escravistamercantil ao qual, com base na exploração do trabalho escravo, cumpria, além da apropriação de parcela substantiva da mesma, a própria criação da mais-valia.

5 "Até nos Estados Unidos, depois que a zona intermediária entre os estados do Norte, em que existia o sistema de trabalho assalariado, e os estados escravistas do Sul, se transformou em uma zona de abastecimento de escravos, portanto, em que o escravo lançado ao mercado escravista se converteu por sua vez em elemento anual de reprodução, chegou o momento em que isto não bastava e foi necessário recorrer pelo maior tempo possível ao tráfico de escravos africanos para abastecer o mercado" (Marx, 1964, II:426).

6 'Embora 'empatada' como capital-dinheiro, a inversão inicial de compra do escravo não se encarna em nenhum elemento concreto do fundo produtivo do escravista. Dito em outras palavras, a inversão inicial de compra do escravo não funciona como capital. No processo real da produção escravista, esta inversão se converte em não-capital. Seria incorreto afirmar que ela é imobilizada, pois assim a incluiríamos no capital fixo. O correto é concluir que o capital-dinheiro aplicado na compra do escravo se transforma em capital-esterilizado, em capital que não concorre para a produção e deixa de ser capital" (grifos de Gorender, 1992:182-183).

7 "O escravo recebe em espécie os meios de subsistência necessários para a sua manutenção e essa forma natural dos mesmos encontra-se fixada, tanto pela sua 
qualidade como pelo seu volume, em valores de uso. O trabalhador livre recebeos sob a forma do dinheiro, do valor de troca; da forma social abstrata da riqueza. Embora o salário não seja, de fato, mais do que a forma áurea, ou argentada ou cúprica ou de papel adotado pelos meios de subsistência, em que tem incessantemente que se resolver - e o dinheiro opera aqui unicamente como forma evanescente do valor de troca, como simples meio de circulação-, na imaginação [do operário] o objetivo e o resultado do seu trabalho continuam a ser, contudo a riqueza abstrata, o valor de troca, não um valor de uso determinado, tradicional e localmente limitado" (grifos de Marx, 1975:87).

“... a fim de ser produtiva, a força de trabalho do escravo terá de ser usada. O trabalho constitui o processo vivo de uso da força de trabalho. A compra do escravo simplesmente o colocou à disposição do dono sem ainda dar a este o uso produtivo da força de trabalho. A fim de usá-la, o plantador não poderá se limitar ao dispêndio feito no ato da compra, mas terá de levar a efeito um novo dispêndio: o do sustento do escravo. Este precisará receber, dia a dia, alimentos, vestuário, abrigo, tempo de repouso, remédios nas eventualidades de doenças etc." (grifos de Gorender, 1992:167).

"O gasto com o sustento diário do escravo - distinto do seu preço de compra é que poderia ser identificado com o capital variável ... se permanecermos obstinados na tese de que o escravismo colonial constitui uma espécie de capitalismo" (Gorender, 1992:182). Como já fizemos notar, não consideramos o escravismo colonial uma "espécie de capitalismo", mas entendemos que no quadro do mesmo se dava a existência de uma forma de capital: o capital escravista-mercantil.

8 "Por conseguinte, concluímos também que a inversão inicial de compra do escravo somente pode ser recuperada pelo escravista à custa do sobretrabalho do escravo, do seu produto excedente. Ela constitui um desconto inevitável da renda ou do que se chamaria de lucro escravista. Do ponto de vista contábil, não faz diferença que seja considerada parcela do custo de produção ou dedução obrigatória do lucro, à semelhança de um imposto. Do ponto de vista da teoria econômica, a única solução correta consiste em incluí-la no produto excedente e considerar a renda efetiva do escravista reduzida na proporção da amortização do investimento feito na aquisição do plantel de escravos" (grifos de Gorender, 1992:183).

9 Cf. Marx, 1964, II, cap. I.

10 "Até nos Estados Unidos, depois que a zona intermediária entre os estados do Norte, em que existia o sistema de trabalho assalariado, e os estados escravistas do Sul, se transformou em uma zona de abastecimento de escravos, portanto, em que o escravo lançado ao mercado escravista se converteu por sua vez em elemento anual de reprodução, chegou o momento em que isto não bastava e foi necessário recorrer pelo maior tempo possível ao tráfico de escravos africanos para abastecer o mercado" (Marx, 1964:426). 
11 Tal tentativa viu-se frustrada pela reação desfavorável das potências européias e dos Estados Unidos à nova nação. Segundo Craton (1995:32) "esse novo e orgulhoso país e sua economia foram imediatamente marginalizados, tanto pelo espírito independente dos próprios haitianos quanto pela calculada indiferença ou o antagonismo ativo, baseado na paranóia racista, das principais potências, inclusive os Estados Unidos".

12 "Ao longo do século XIX, o Haiti teve a mais baixa porcentagem de trabalhadores sem terra entre todas as ilhas das Antilhas" (Foner, 1988:30).

13 Nas colônias britânicas espalhadas por todo o mundo, algo em torno de 700 mil pessoas foram libertadas, 311 mil só na Jamaica e 83 mil em Barbados.

14 No mesmo sentido, Craton afirma "resultasse ou não da freqüentemente alegada tendência nacional britânica no sentido da mudança evolutiva, em vez da revolucionária, e de uma concomitante facilidade de adaptação pragmática, o processo nas Índias Ocidentais Britânicas demonstrou aspectos de um continuum com antecipações e sobrevivências de cada lado da emancipação formal dos escravos, em lugar de fases profundamente marcadas e mudanças abruptas" (Craton, 1995:33).

15 A controvérsia fundamental opõe Williams e Drescher. O primeiro atribui ao interesse inglês razões de ordem fundamentalmente econômica, relacionadas ao declínio da importância dos fluxos de produção e comércio de mercadorias e escravos entre a Inglaterra e Antilhas e a incompatibilidade entre as exigências do desenvolvimento do capital industrial inglês e o escravismo. Seymour, baseado em amplo conjunto de dados, procura mostrar que aos anos imediatamente anteriores ao fim do tráfico de escravos corresponderam volumes ascendentes de exportações de algodão e açúcar das Antilhas para a Inglaterra, ocorrendo o mesmo com o tráfico de escravos. As razões básicas relacionadas ao fim do tráfico e posterior abolição, segundo este autor, devem ser buscadas, sobretudo, no movimento abolicionista. Para maiores detalhes ver Williams (1975) e Drescher (1977).

16 O eixo fundamental da análise seguinte baseia-se em Moore Jr. (1975:141-189).

17 Seria, no entanto, um erro grosseiro atribuir homogeneidades estritas em relação ao trabalho escravo no interior das sociedades nortista e sulista. Da mesma forma como existia um grupo significativo de pessoas no Norte, quiçá majoritário, indiferentes à sorte dos negros e, por certo, indivíduos favoráveis à escravidão, havia vários brancos sulistas simpáticos à causa abolicionista (Cf. Foner, 1988:73).

18 Para maiores detalhes a respeito dos republicanos radicais e suas políticas durante o período da "Reconstrução" e sua derrota para o Partido Democrata com a "Redenção", veja-se Foner (1988, especialmente p. 73-176) e Moore Jr. (1975:183-189). 
19 "A Espanha havia prometido aos britânicos desde 1817 abolir o tráfico de escravos, e em 1835 permitiu que seus navios fossem revistados e julgados os traficantes espanhóis por autoridades britânicas" (Cardoso \& Brignoli, 1983:151).

20 "They [os casos levados perante as Juntas] show the inadequacy of conceptualizing slave and patrocinado behavior in terms of 'accomodation' or 'resistance', and the necessity of analyzing that behavior in terms that reflect the complexity of 'patrocinados' goals and strategies" (Scott, 1985:141).

21 "O artigo 4 da lei de 1880 enumerava as obrigações do patrono: manter seus patrocinados, vesti-los, dar assistência aos doentes, pagar o estipêndio mensal estipulado, educar os menores, alimentar, vestir e dar assistência quando doentes aos filhos de seus patrocinados" (Scott, 1987:473).

22 As discussões encaminhadas no Parlamento Inglês para pôr termo ao tráfico de escravos iniciam-se em 1783, estabelecendo-se, por fim, a proibição do tráfico para os súditos britânicos a partir de 1807. Nos anos posteriores seguiram-se Dinamarca, Portugal, Chile, Suécia e Holanda. A extinção do tráfico por parte da Espanha demorou mais a efetivar-se, em virtude da sensibilidade da corte espanhola aos interesses econômicos dos proprietários de escravos, sobretudo cubanos e porto-riquenhos (para outros detalhes vide Saco, 1965:213-229).

Referências bibliográficas

BEIGUELMAN, Paula. A formação do povo no complexo cafeeiro: aspectos politicos. São Paulo, Pioneira, 1977.

CARDOSO, Ciro Flamarion S. \& BRIGNOLI, Héctor Pérez. História econômica da América Latina. Rio de Janeiro, Graal, 1983.

CASTRO, Antônio Barros de. A economia política, o capitalismo e a escravidão. In: Lapa, J.R. do Amaral (org.). Modos de produção e realidade brasileira. Petrópolis, Vozes, 1980, p. 67-107 (Coleção história brasileira, 5).

CRATON, Michael. Reembaralhando as cartas: a transição da escravidão para outras formas de trabalho no Caribe britânico (c. 1790-1890). Rio de Janeiro, Centro de Estudos Afro-Asiáticos, Estudos Afro-Asiáticos. 28, p. 31-83, out. 1995.

DONGHI, Tulio Halperin. História da América Latina, $2^{\mathrm{a}}$ ed. Rio de Janeiro, Paz e Terra, 1975.

DRESCHER, Seymour. Capitalism and the decline of slavery: the British case in comparative perspective. In: Rubin, V. \& Tuden, A. (eds.). Comparative perspective on slavery in the New World plantation. New York, The New York Academy of Sciences, 1977. 
FONER, Eric. Nada além da liberdade: a emancipação e seu legado. Rio de Janeiro, Paz e Terra, 1988.

GORENDER, Jacob. O escravismo colonial, 6ª ed. São Paulo, Ática, 1992 (Ensaios, 29).

Questionamentos sobre a teoria econômica do escravismo colonial. Estudos Econômicos, v. 13, n. 1, p. 7-39, jan./abr. 1983.

HOLT, Thomas C. "A essência do contrato": a articulação de raça, gênero e economia na política de emancipação britânica (1838-1866). Rio de Janeiro, Centro de Estudos Afro-Asiáticos, Estudos Afro-Asiáticos, 28, p. 9-30, out. 1995.

MARX, Carlos. El Capital: crítica de la Economia Politica. México-Buenos Aires, Fondo de Cultura Econômica, v. I e II, 1964, v. III, 1965. (As citações foram traduzidas para o português pelos autores com base neste original).

- Elementos fundamentales para la crítica de la economía política (Grundrisse) 1857-1858, $11^{2}$ ed. México D.F., Siglo Veintiuno Editores, v. 1, 1980. (As citações foram traduzidas para o português pelos autores com base neste original).

Capitulo inédito d'O Capital: resultados do processo de produção imediato. Porto, Publicações Escorpião, 1975 (Biblioteca Ciência e Sociedade, 12).

MOORE Jr., Barrington. As origens sociais da ditadura e da democracia: senhorese camponeses na construção do mundo moderno. Lisboa, Edições Cosmos; Santos, Livraria Martins Fontes, 1975.

PRADO JÚNIOR, Caio. Formação do Brasil contemporâneo: colônia, 20ª ed. São Paulo, Brasiliense, 1987.

SACO, J.A. Historia de la esclavitud. Buenos Aires, Andina, 1965.

SCOTT, Rebecca J. Abolição gradual e a dinâmica da emancipação dos escravos em Cuba, 1868-86. São Paulo, IPE-USP, Estudos Econômicos, v. 17, n. 3, p. 457-485, set./dez. 1987.

Slave emancipation in Cuba: the transition to free labor, 18601899. Princeton, Princeton University Press, 1985.

WILliAMS, Eric. Capitalismo e escravidão. Rio de Janeiro, Cia. Editora Nacional, 1975.

RESUMO - NESTE artigo propõe-se como forma de entender com maior profundidade a formação econômica brasileira nos períodos colonial e imperial, o conceito 
de capital escravista-mercantil. Trata-se de uma forma específica de existência do capital, diversa do capital comercial, usurário e industrial, cuja fórmula e propriedades principais encontram-se aqui expostas. Busca-se, ademais, aquilatar as principais conseqüências, do ponto de vista teórico e empírico, da existência desta forma particular de capital para a economia e sociedade brasileiras, estabelecendose um debate com a historiografia pertinente.

ABSTRACT - THE CONCEPT of slave-mercantile capital is proposed in this article as a way to understand in greater depth the Brazilian economic formation during the colonial and imperial periods. It consists of a specific form of existence of capital, different from commercial, industrial and usury capital, whose formula and main properties are presented here. Moreover, in this paper is tried to appraise the major consequences of the existence of this particular form of capital for Brazilian economy and society, from theoretical and empirical points of view, establishing a debate with the relevant historical literature.

Julio Manuel Pires é professor doutor da Faculdade de Economia, Administração e Contabilidade da Universidade de São Paulo, campus de Ribeirão Preto.

Iraci del Nero da Costa é professor livre-docente da Faculdade de Economia, Administração e Contabilidade da Universidade de São Paulo. 